\title{
Perspectives on Literacy as a Tool for Sustainable Social Relationship
}

\author{
Osalusi, F. M. \\ Faculty of Education, \\ Ekiti State University, Ado-Ekiti. Nigeria \\ E-mail: osalusiflo2009@gmail.com \\ Oluwagbohunmi, M. F. \\ Faculty of Education, \\ Ekiti State University, Ado-Ekiti. Nigeria \\ E-mail: gbohunmi7@gmail.com
}

Received: 02-11- 2013

Accepted: $18-12-2013$

Published: $31-01-2014$

doi:10.7575/aiac.ijels.v.2n.1p.40

URL: http://dx.doi.org/10.7575/aiac.ijels.v.2n.1p.40

\begin{abstract}
This study investigated perspectives on literacy as a tool for sustainable relationship among people. The study was conducted due to the significant role of literacy as an instrument of empowerment to improve relationship with other people by sharing information, ideas and knowledge to meet variety of purposes. The study adopted descriptive research design of the survey type. A sample of 1675 respondents that comprised of 1032 literates and 643 illiterates was selected through purposive and simple random sampling techniques from two local government areas of Ekiti state, Nigeria. An instrument tagged 'Perception of Literacy for Social Relationship Questionnaire (PLHLSRQ)' was used to collect data from the respondents. The instrument was validated by experts and tested for reliability at 0.71 coefficients through test-re-test method. Data collected were statistically analysed using mean, standard deviation and student t-test at 0.05 level of significance. The result of the study showed a significant difference between literates and illiterates' perspectives on literacy as a tool for sustainable social relationship. The study also revealed significant gender difference in perspectives on literacy for sustainable social relationship. Based on the findings, it was recommended among others that government should organise more awareness and sensitization programmes and seminars to purposefully attract illiterate commercial drivers and riders to literacy programmes.
\end{abstract}

Keywords: Literacy, understanding information, social relationship, illiteracy, violent acts, societal sustainability

\section{Introduction}

In this modern age, literacy has gone beyond being recognised as mere reading, writing and numeracy. It has developed into reading to acquire knowledge and writing to critically understand whatever is written. Traditionally, literacy is defined as the ability to read, write and calculate at an adequate level of proficiency that is necessary for communication (Dada, 2011). The United Nations Educational, Scientific and Cultural Organisation (UNESCO, 2004) defines literacy as the ability to identify, understand, interpret, create, communicate and compute using printed and written materials associated with varying contexts. Literacy involves a continuum of learning in enabling individuals to achieve their goals, to develop their knowledge and potentials and to participate fully in their community and wider society. Literacy forms the foundation of education which enables individuals to be conscious of their environment, earn a living, develop right type of values and attitude, imbibe socially acceptable behaviours and learn the rudiments of peaceful coexistence with other people.

According to Jegede, Ojo-Ajibare, Eneme, and Aitokhuehi, (2010), literacy is value-laden, routed in development and is a tool for changing one's world view, perception, value system, outlook of events and situations. In recent times, the people living with AIDS in Nigeria converged at the National Assembly to show their grievance and protest against non passage of the bill against their stigmatization. This move was possible due to awareness, knowledge and literacy level of the affected people that opened their eyes to the fact that they should not be discriminated against or stigmatized. Passage of the bill (which the Assembly members promised to effect very soon) would encourage people to have unhindered relationship with them, thereby strengthening relationship among people and ensuring sustainability of the society. Literacy is very essential in social and human development due to its ability to transform lives. It opens peoples' eyes and introduces them to pools of information and knowledge pieces that could bring about a change in their attitude and dispositions (Ajibola, Akpan, Ogunjimi and Emeribe, 2011). It is an instrument of empowerment to improve relationship with people around and in the world. Literacy from this perspective is viewed as a social practice. These writers are of the view that illiteracy could hinder smooth relationship among people. The thinking and reasoning ability of illiterates always appear to be different from that of literates. Their perception of life and approach to people and issues seem to be different too. In actual fact, their contribution to discussions on sensitive matters and reaction to issues usually seem to result in violence. 
Observations have shown that misunderstanding among commercial drivers and motor cycle (locally called 'okada') riders in most Nigeria communities usually result in fight, culminating into violence through which many lives have been lost. Matters which literates would handle carefully or simply overlook before they generate serious heat are mostly taken as opportunity to foment trouble and show grievance over one thing or the other by the illiterates. The illiterates are used as thugs by politicians and political office holders. Their function is to maim, kill, destroy or cause trouble at the instruction of their master. They constitute touts (young men who earn their living by boasting or bragging aggressively) found in motor parks. Violent acts of commercial drivers and motor cycle riders which has become a common phenomenon in the society has continued unabated due to their low literacy level as most of them who claim to be educated are primary or secondary school drop outs that cannot boast of any certificate. Most of them have never deemed it fit to attend literacy programmes to upgrade themselves not to talk of going back to school. The literacy programmes organised by government are mostly attended by old market women (traders) who deem it necessary to learn basic arithmetic needed for calculations in their trade.

The Boko Haram insurgence being experienced in the northern part of Nigeria is observed to be the resultant effect of illiteracy. This rebellious sect has been involved in the dastardly act of killing innocent Nigerians for just no cause thereby causing insecurity of lives and properties. While commenting on the viciousness of the sect, Musa (2013) writes that "more worrisome is the inhuman way the terrorists perpetrate their dastardly acts ranging from outright shooting, macheting and slaughtering of their victims using knives and sometimes saw machines from the back of the victims' necks till the heads are severed. In some cases, victims' throats were savagely slashed. Abimbola and Adesote (2012) declare that not less than 1,200 persons including civilians, security personnel have been killed since its emergence up to February, 2012.

The reason for this wicked act as averred by Adesoji (2010) is that the movement is not only characteristically opposed but outrightly rejects western education, western culture and modern science. Danjibo (2009) in Abimbola and Adesote (2012) claims the Islamic sect believe that an imported system of government based on 'western values' has resulted in ostensible corruption, poverty, unemployment and the continued suppression of true Islam in the northern part of Nigeria. In an attempt to remove moral decadence and evils caused by the embrace of western civilization in the society, the Islamists started destroying modern political institutions and infrastructures. They unleash terror on government establishments destroying properties and deliberately killing innocent people found in places where they strike.

\section{Review of Related Literature}

Literacy is defined by International Adult Literacy Survey (IALS, 1995) researchers as the ability to understand and employ printed information in daily activities in both domestic and social life and at work to achieve one's goals, and to develop one's knowledge and potential. Studies have revealed that in order to live a standard life with socially acceptable attitudes and behaviours, certain level of literacy must be attained. Literacy opens peoples' eyes and introduces them to pools of information and knowledge pieces that could bring about a change in their attitude and dispositions (Ajibola, Akpan, Ogunjimi and Emeribe, 2011).

A literate person in this modern age should be able to understand and use information and written texts purposefully for self-development and improved relationship with others. Ogbonna (2003) believes that an individual's ability to search for and obtain needed information makes him an educated person. Feldman et al (1989) in Cornali (2011) submits that an educated person is able to accomplish daily duties with confidence and face unforeseen events; for these reasons, he is for the most part held in high esteem. This implies that literates would not want to do anything that will tarnish their image unlike some illiterates who claim not to have any name or image to protect and boastfully refer to themselves as 'accused persons' having several unsettled cases with the police. In the study conducted by Aladenusi and Ayodele (2011) on perception of literates and illiterates on leadership education, it was found that literates have more positive perception towards leadership education compared to their illiterate counterparts in Nigeria. They emphasized that education is a veritable tool for creating a sound mind in a sound body in a peaceful environment.

Although, the level of completed education is one of the most important predictors of many forms of political and social engagement (Cornali, 2011), Schuller et al. (2001) in Cornali (2011) found that education, other things constant, increases political participation and civic participation. Studies on gender illustrate that out of 1 billion illiterates in the world, two thirds of them are women and that the families of women with some education tend to have better housing, clothing, income, water and sanitation (Women Literacy, 2010). UNDP, in its Human Development Report in New York (1999) discloses that high level of literacy skill among adults showed a positive relationship with female representation in government positions while Beherman and Stacey (1997) also affirm that high level of literacy skill among adults revealed a positive correlation with lower crime rates among women. Shaik and Abdul-Rasheed (2012) found that girls scored better in all skills results and their attitude is also more favourable towards reading in English. The Programme for International Student Assessment (PISA) indicates that in every country tested, females on average reach higher levels of performance in reading literacy than males.

Literacy is a pre-requisite for ensuring that people maintain smooth relationship with one another and that peace reigns in our environment. The knowledge and information needed for sustainable social relationship, most especially on fundamental human rights and how to protect them are acquired through education. Hasaba (2013) believes that the absence of literacy skills makes it difficult to attain fundamental needs, to uphold basic human rights and advance a better quality life. UNESCO (2004) maintains that a literate community is a dynamic community where ideas are 
exchanged for societal development and illiteracy is an obstacle to a better quality of life and can breed exclusion and violence.

If illiteracy can surely breed violence as claimed by UNESCO, then it will not be out of place to say that the security problems being experienced by Nigerians via Boko Haram insurgents has its base in illiteracy. Since its inception in 2001, the Jihadists have been responsible for roughly 10,000 deaths (Allen, 2013). Although, the dastard act has been condemned by Nigerians, it still remains the most vicious attack against humanity. Marshal (2012), while commenting on the causes of Boko Haram outrightly points out that if there is any help to give the Northern Nigeria, it is to enlighten them on the need to strike a balance between Quranic education and western education. He enjoins the federal government to divert funds allocated to 'Almajiri' education to western education (the foundation of which is literacy) through which the youths could obtain certificates that would qualify them to apply for jobs.

\section{Statement of the Problem}

It appears there is an individual difference in the way people behave and relate with one another. For people to build strong relationship with one another, there is need to share information, ideas and knowledge to meet variety of purposes, most importantly to solve problems. Literacy status can influence thinking and reasoning ability of people and it requires certain level of education/literacy for people to understand that every human being has right to live and that other basic rights must be respected. It seems the people being used as Boko Haram insurgents in Nigeria are illiterates that do not have respect for human dignity and attach no importance to the human lives which they waste willfully. It has been observed that the commercial drivers and motor cycle ('okada') riders usually pick up little quarrel until it is fueled to violence and killing of people. Killing of innocent citizens has so much strained social relationships to the extent that people now move about with suspicions and restrictions. It is on this premise that this study was conducted to find out if differences exist in peoples' perspectives on literacy as a tool for maintaining social relationship.

\section{Purpose of the Study}

The purpose of this study was to find out if differences exist in peoples' perspectives on literacy as a tool for sustainable social relationship between literates and illiterates and between male and female respondents.

\subsection{Research Question}

Do people perceive literacy as a tool for maintaining social relationship?

\subsection{Research Hypotheses}

The following hypotheses were raised for the study:

$\mathrm{Ho}_{1}$ : Perspectives on literacy as a tool for sustainable social relationship will not significantly differ between literates and illiterate.

$\mathrm{Ho}_{2}$ : There will be no significant difference between male and female respondents' perspectives on literacy as a tool for sustainable social relationship.

\section{Methodology}

The study adopted descriptive research design of the survey type. A sample of 1,675 respondents that comprised of 1032 literates (mainly government workers) and 643 illiterates (commercial drivers, 'okada' riders, farmers and petty traders) were selected through purposive and simple random sampling techniques from two local government areas of Ekiti state. An instrument tagged 'Perspectives on Literacy for Social Relationship Questionnaire (PLSRQ)' was used to collect data from the respondents. The instrument which had three sections was a self designed questionnaire. Section A elicited information on the respondents' biodata such as sex, occupation and literacy status while Section B contained questionnaire items on relevance of literacy to sustainable social relationship. The instrument was validated by experts and tested for reliability by using test-re-test method which yielded 0.71 coefficients. Administration of the instrument was done by the researcher with the assistance of some research assistants. The questionnaire items were verbally interpreted in 'Yoruba' language to many of the illiterates before they could give their responses. They were also assisted to tick their responses. Data collected were statistically analysed with mean, standard deviation and t-test. The two hypotheses generated for the study were tested at 0.05 level of significance.

\section{Results}

Research Question: Do people perceive literacy as a tool for maintaining social relationship?

Table 1. Perspectives on literacy as a tool for maintaining social relationship

\begin{tabular}{lcccc}
\hline \multicolumn{1}{c}{ Items } & Agree & $\%$ & $\begin{array}{c}\text { Dis- } \\
\text { agree }\end{array}$ & $\%$ \\
\hline $\begin{array}{l}\text { Literacy is an instrument that can improve relationship among } \\
\text { people }\end{array}$ & 784 & 75.7 & 248 & 24.3 \\
\hline $\begin{array}{l}\text { Peaceful co-habitation among people depends on individual's } \\
\text { literacy level }\end{array}$ & 537 & 52 & 495 & 48 \\
\hline Active participation in social activities requires literacy & 381 & 37 & 651 & 63 \\
\hline
\end{tabular}




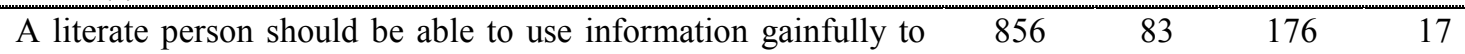
maintain smooth relationship with other people

\begin{tabular}{|c|c|c|c|c|}
\hline $\begin{array}{l}\text { Literacy enables people to know their rights and how to claim } \\
\text { them }\end{array}$ & 970 & 94 & 62 & 06 \\
\hline $\begin{array}{l}\text { To understand the fundamental human rights and protect them } \\
\text { depends on literacy level of individuals }\end{array}$ & 743 & 72 & 289 & 28 \\
\hline $\begin{array}{l}\text { Illiterates are more likely to believe in negative rumors that can } \\
\text { cause chaos than literates }\end{array}$ & 721 & 69 & 311 & 31 \\
\hline $\begin{array}{l}\text { Ignorance is one of the factors militating against smooth } \\
\text { relationship among Nigerians }\end{array}$ & 495 & 48 & 537 & 52 \\
\hline Literacy allows people to be alive to their civic responsibilities & 598 & 58 & 434 & 42 \\
\hline Literates are not as destructive as some illiterates & 660 & 64 & 372 & 36 \\
\hline $\begin{array}{l}\text { Most commercial drivers and riders easily pick up quarrels and } \\
\text { misbehave because they are illiterates }\end{array}$ & 846 & 82 & 186 & 18 \\
\hline $\begin{array}{l}\text { Literates always strive to maintain smooth relationship with } \\
\text { other people }\end{array}$ & 722 & 70 & 310 & 30 \\
\hline $\begin{array}{l}\text { Some illiterates like to cause trouble not minding the } \\
\text { consequence }\end{array}$ & 526 & 51 & 506 & 49 \\
\hline $\begin{array}{l}\text { The Boko Haram terrorists are killing people because they are } \\
\text { wicked illiterates that oppose western education }\end{array}$ & 1009 & 97.8 & 23 & 2.2 \\
\hline $\begin{array}{l}\text { Most illiterates take up menial jobs, are easily offended and } \\
\text { angered }\end{array}$ & 588 & 57 & 444 & 43 \\
\hline $\begin{array}{l}\text { Most of the boys used as political thugs and motor park touts that } \\
\text { usually cause trouble are illiterates }\end{array}$ & 939 & 91 & 93 & 09 \\
\hline Literates command respect and are usually held in high esteem & 701 & 67 & 331 & 33 \\
\hline Literacy increases political and civic participation & 639 & 62 & 393 & 38 \\
\hline Only literate people can contest elective posts. & 939 & 91 & 93 & 09 \\
\hline Total & 13654 & 69.63 & 5963 & 30.37 \\
\hline
\end{tabular}

Table 1 shows that a large number of respondents agreed that the Boko Haram terrorists are killing people because they are wicked illiterates that oppose western (97\%) and literacy enables people to know their rights and how to claim them (94\%). The table also reveals that $91 \%$ agreed that most of the boys used as political thugs and motor park touts that usually cause trouble are illiterates while most commercial drivers and riders easily pick up quarrels and misbehave because they are illiterates $(82 \%)$. On the average, about $70 \%$ of the respondents agreed that literacy is an important tool for sustainable social relationship.

\section{Testing of Hypotheses}

$\mathbf{H 0}_{1}$ : Perspectives on literacy as a tool for sustainable social relationship will not significantly differ between literates and illiterates

Table 2. t-test analysis on difference in perception of literacy for sustainable social relationship between literates and illiterates

\begin{tabular}{lccccccc} 
Source of Variation & $\mathrm{N}$ & $\mathrm{X}$ & $\mathrm{Sd}$ & $\mathrm{Df}$ & $\mathrm{t}$-cal & t-value & Decision \\
\cline { 1 - 5 } Literates & 1032 & 30.07 & 7.81 & & & & \\
\cline { 1 - 5 } Illiterates & 643 & 24.68 & 5.09 & 1673 & 2.470 & 1.96 & Significant \\
\hline
\end{tabular}

From Table 2, it can be seen that t-cal (2.470) is greater than t-value (1.96). This shows a significant difference in literates and illiterates' perception of literacy as a tool for sustainable social relationship. The hypothesis is hereby rejected.

$\mathbf{H O}_{2}$ : There will be no significant difference between male and female respondents' perspectives on literacy as a tool for sustainable social relationship 
Table 3. t-test analysis on gender difference in perception of literacy as a tool for sustainable social relationship

\begin{tabular}{lcrrrrrl}
\hline Gender & $\mathrm{N}$ & $\mathrm{X}$ & $\mathrm{Sd}$ & $\mathrm{Df}$ & $\mathrm{t}$-cal & t-value & Decision \\
\cline { 1 - 5 } Male & 923 & 39.57 & 9.27 & & & & \\
\cline { 1 - 6 } Female & 752 & 38.02 & 11.00 & 1673 & 1.045 & 1.96 & Not Significant \\
\hline
\end{tabular}

Table 3 shows that the t-calculated (1.045) is less than t-value (1.96). This implies that there is no significant gender difference in the perception of literacy as a tool for sustainable social relationship. The hypothesis is therefore not rejected.

\section{Discussion of Findings}

Findings of this study have shown that the Boko Haram terrorists are killing people because they are wicked illiterates that oppose western literacy enables people to know their rights and how to claim them. Table 1 also reveals that most of the boys used as political thugs and motor park touts that usually cause trouble are illiterates while most commercial drivers and riders easily pick up quarrels and misbehave because they are illiterates. Most of the respondents agreed that literacy is an important tool for maintaining social relationship among people. This implies that literates make use of knowledge and information acquired through education to live and co-exist peacefully with one another. This also helps them to eschew violence. That some of the illiterates are easily angered, offended and pick quarrels, that in most cases result in violence, may be attributed to the fact that they are usually tensed up on their menial jobs that take much suffering and exertion but earn them paltry sum of money. Their problem can also be as a result of inability of the drop outs among them to go back to school to acquire certificate that would earn them good job and good pay.

This study showed a significant difference between literates' and illiterates' perception of literacy as a tool for maintaining sustainable social relationship. Table 2 shows 30.07 as mean score for literates and 24.68 for illiterates. This has the implication that literates have positive perception of literacy as a veritable tool for sustainable social relationship. Positive perception of literates could be attributed to their level of education that make them to be held in high esteem as claimed by Feldman et al (1989) in Cornali (2011) as a result of which they would not want to misbehave or carry out any act that will tarnish their image. It could also be attributed to the awareness and knowledge gained by the literates in the course of education received through which they were taught the duties, roles, obligations, rights of individuals and laws of the society and the punishment for defying the laws of the land.

The study also revealed that there is no significant gender difference in the perception of literacy as a tool for sustainable social relationship. The implication of this is that male and female respondents did not differ in their perception of literacy as a tool for maintaining social relationships. It further led credence to the fact that literacy is an important factor in ensuring that people put up normal behaviour, good virtues and values and develop socially accepted habits necessary for building strong relationships that can eventually culminate in maintaining social sustainability.

\section{Conclusion and Recommendations}

This paper has examined literacy as a tool to ensure sustainable relationship among people. Findings of the study have shown that literacy is a pre-requisite for ensuring that peace reigns in our environment and that absence of literacy skills can breed violence. In view of the findings, it is recommended that government should make effort to include all illiterates (irrespective of gender or type of work) in its literacy programmes. Giving incentives to learners and rewarding good performance in literacy classes can be introduced while more awareness and sensitization programmes and seminars should be organised to purposefully attract and invite illiterate drivers and riders to literacy programmes. Government can also design means of enlightening members of the Boko Haram sect and their northern Muslim supporters on the unquantifiable values of western education.

\section{References}

Abimbola, J. O. \& Adesote, S. A. (2012). Domestic terrorism and Boko Haram insurgency in Nigeria, issues and trends: a historical discourse. Journal of Arts and Contemporary Society, 4 , September, 2012, 11-29.

Adesoji, A. (2010). The Boko haram uprising and Islamic revivalism in Nigeria. Africa Spectrum, 45 (2), 95-108.

Ajibola, C.A; Akpan, S.C; Ogunjimi, L.O. \& Emeribe, V.C. (2011): Literacy for cultural reformations: its perspective in the control of HIV/AIDS. In B.O. Ogundele; O.A. Moronkola \& J.F. Babalola Contemporary Issues in Education, Health and Sports: The Way Forward. Book of Reading, Department of KHE, University of Ibadan, 109-122

Aladenusi, O. \& Ayodele, K.O. (2011): Public perception of leadership education as a veritable tool for good governance and democratic development in Nigeria. Research in Curriculum Studies, 6 (1), 159-166.

Allen, J.L. (2013): The catholic church: what everyone needs to know. In 'Boko haram'- Wikipedia- the free encyclopedia (saharareporters.com). Accessed 29/05/2013

Beherman, J.R. \& Stacey, N. (1997 eds.): The social benefits of education. The University of Michigan Press, 1997. 
Cornali, F. (2011): The strange relationship between literacy and well-being: the results of an International survey with special focus on Italy. International Journal of Human and Social Science. V6-2-11-pdf pp67-76. Accessed on 28/05/2013 from Wikipedia (2013)

Dada, E.M. (2011): New literacies and its challenges for teacher education in Nigeria. Research in Curriculum Studies, $6(1), 110-117$.

Hasaba, S. (2013): Making adult literacy learning sustainable in rural communities. unu.edu/publications/articles/making.html. Accessed on 08/06/2013.

International Adult Literacy Survey (IALS, 1995): Results of the First International Adult Literacy Survey. ParisOttawa: Organisation for Economic Co-operation and Development (OECD) countries.

Jegede, O.I; Ojo-Ajibare, J.O; Eneme, P.I. \& Aitokhuehi, O.O. (2010): Literacy as a tool for fostering political emancipation. A paper presented at the 2010 Conference of the Nigerian National Council of Adult Education (NNCAE) held at University of Ibadan, $7^{\text {th }}-9^{\text {th }}$ December.

Marshal, B. (2012): The real cause of boko haram and northern underdevelopment. Nairaland Forum. www.nairaland.com /926228/real-cause. Accessed on 26/05/2013

Shaik, Abdul M.M.I. \& Abdul Rashid, M. (2012): Girls, Boys ESL reading comprehension ability in Malaysia. A paper presented at London International Conference on Education, November; 2012

UNDP (1999): Human Development Report. New York: UNDP.

UNESCO (2004): The plurality of literacy and its implications for policies and programmes. Education Sector Position Paper: 13. www.unesco.org/en/literacy. Accessed on 08/06/2013

Women’s Literacy (2010): Women and Literacy. www.sil.org/literacy/wom lit.html Accessed on 08/06/2013. 